\title{
Analisis Implementasi Cash Waqf Linked Sukuk (CWLS) Perspektif Prinsip Ekonomi Syariah
}

\author{
Riska Delta Rahayu \\ Universitas Islam Negeri Sunan Ampel Surabaya, Indoensia \\ riskadelta99@gmail.com \\ Moh. Andre Agustianto \\ Universitas Islam Negeri Sunan Ampel Surabaya, Indonesia \\ mochammad.andre@uinsby.ac.id
}

\begin{abstract}
Waqf played two important roles in Islamic history, namely in economic as well as social. An innovation in developing waqf is the Cash Waqf Linked Sukuk (CWLS) which is an integration between the waqf funds invested through State Sharia Securities (SBSN) or Sukuk. This study aims to examine the role of CWLS in the economy and society based on an Islamic economic perspective. This research is a type of library research (literature study) with a qualitative approach. The implementation of Cash Waqf Linked Sukuk management has been carried out in accordance with an Islamic economic perspective which is based on sharia principles and has been determined in accordance with the DSN-MUI Fatwa on Sukuk Waqf. The results of the study reveal that the implementation of CWLS has also met the required pillars and in managing the waqf funds it is allocated for halal activities and according to sharia principles. Cash Waqf Linked Sukuk has the potential for economic and social development in society because it aims to achieve the benefit and welfare of the community in general.
\end{abstract}

Keywords: Cash Waqf Linked Sukuk, Sharia Principles, Benefit

\section{Latar Belakang}

Wakaf memainkan dua peran penting dalam sejarah Islam yaitu dalam ekonomi sekaligus sosial. Sehingga wakaf berfungsi sebagai sumber pembiayaan bagi masjid-masjid, pelayanan sosial, pelayanan pendidikan, pelayanan kesehatan dalam rangka mencapai kesejahteraan masyarakat. Pemahaman wakaf tidak yang hanya terbatas pada asset atau benda tidak bergerak saja namun lebih kompleks ke dalam benda yang bergerak yang disebut wakaf uang atau wakaf tunai. Wakaf tunai memiliki sifat yang fleksibel, dimana wakaf tunai memilih jumlah yang variatif sehingga 
seseorang yang memiliki dana terbatas pun dapat memberikan dana wakafnya. Wakaf tunai juga memiliki manfaat yang dapat digunakan untuk memberdayakan aset-aset wakaf yang berupa benda tidak bergerak yang belum dikelola secara produktif. Wakaf tunai ini juga sering disebut dengan wakaf produktif karena dapat memproduktifkan benda wakaf yang dapat menghasilkan keuntungan yang berkelanjutan sehingga keuntungan tersebut dapat menjadi sumber dana abadi bagi pembiayaan kebutuhan umat.

Dengan mayoritas penduduk muslim terbesar mencapai $87 \%$, potensi wakaf di Indonesia sangat besar jika bisa dioptimalkan dan mampu memberi kontribusi positif terhadap perekonomian nasional. Dengan diterbitkannya UU No. 41 Tahun 2004 tentang Wakaf, mendorong untuk memberdayakan wakaf uang sebagai instrumen membangun kehidupan sosial ekonomi umat Islam. ${ }^{1}$ Melihat peluang besar dalam pemanfaatan asset wakaf di Indonesia yang mencapai 414 juta hectare yang apabila dinominalkan yaitu sebesar $\mathrm{Rp} 2.050$ triliun mendorong untuk memberdayakan idle asset atau wakaf yang belum produktif tersebut. Di Indonesia, wakaf tidak hanya terbatas pada wakaf tanah saja, namun lebih lanjut kepada instrumen-instrumen yang mendorong masyarakat dalam berwakaf, seperti wakaf tunai yang dikolaborasikan dengan sukuk yang disebut Cash Waqf Linked Sukuk (CWLS). Instrumen dari lahirnya sukuk berbasis wakaf ini diinisiasi oleh Bank Indonesia, Badan Wakaf Indonesia, dan Kementerian keuangan.

Sukuk merupakan suatu bentuk produk yang paling inovatif yang dihadirkan dalam rangka pengembangan sistem keuangan syariah di masa kontemporer. ${ }^{2}$ Sukuk memberikan alternative sumber pendanaan bagi pemerintah maupun korporasi. Dengan adanya insturmen CWLS berpotensi untuk mengoptimalkan asset wakaf, dimana sukuk yang diintegrasikan dengan wakaf ini berfungsi untuk memberdayakan banyaknya tanah wakaf yang tidak produktif. Sukuk berperan sebagai instrumen untuk memobilisasi sedangkan wakaf memiliki kapasitas dalam mendapatkan income dana aktifitas keuangan yang produktif. Oleh karena itu kolaborasi antara sukuk dan wakaf ini dapat menjadi inovasi dalam menyediakan pembiayaan dalam rangka pembangunan ekonomi yang berkelanjutan. Disisi lain, selain dari begitu banyak keunggulan instrumen wakaf tersebut, peneliti ingin menelaah bagaimana peranan Cash Waqf

${ }^{1} \mathrm{H}$. Setyahadi (2017), "Pengelolaan Pengembangan Wakaf Uang Berdasarkan Peraturan PemerintahNo. 42 Tahun 2006 Pasal 48 pada Bank BPD DIY Syariah", IQTISHADUNA: Jurnal Ekonomi Syariah, 2 (1), 52-61.

${ }^{2}$ Muhammad Iqbal Fasa (2016), “Sukuk: Teori dan Implementasi”, Li Falah: Jurnal Studi Ekonomi dan Bisnis Islam, 1(1), 2016, 80. 
Linked Sukuk bagi ekonomi dan sosial serta mengkaji penerapan Cash Waqf Linked Sukuk berdasarkan kesuaiannya dengan prinsip ekonomi Islam.

Melihat begitu signifikan dan konstributifnya CWLS ini dalam mengembangkan ekonomi umat, serta ditopang oleh sifat "inovasi" sebagai karakter utama, maka perlu dianalisis konten dan cara mainnya dengan berpijak pada prinsip ekonomi syariah. Karena bagaimanapun, segala bentuk ekonomi yang terkait dengan ke-syariah-an diperlukan kajian tertentu untuk melahirkan pemahaman apakah CWLS ini sesuai dengan prinsip syariah atau tidak. Oleh karena itu, peneliti tergerak untuk melakuan kajian an sic tentang analisis CWLS dalam koridor prinsip ekonomi Islam.

\section{Kerangka Teori}

\section{Pemaknaan Wakaf dalam Islam}

Wakaf berasal dari bahasa Arab yaitu al-waqf yang berarti menahan atau menghentikan. Menurut Imam Nawawi, wakaf ialah menahan harta yang dapat diambil manfaatnya tetapi bukan untuk dirinya, sementara benda itu tetap ada padanya dan digunakan manfaatya untuk kebaikan dan mendekatkan diri kepada Allah. Al-Murghniy mendefinisikan wakaf dengan menahan harta dibawah tangan pemiliknya disertai dengan memberikan manfaat sebagai sedekah (hasbul 'aini ala maliki al-Wakif wa tashaduq bi al-manfi'ah). Menurut Sayyid Sabiq, wakaf merupakan menahan harta sehingga harta tersebut dapat memberikan manfaat di jalan Allah. Abu Hanifah mengartikan wakaf dengan menahan suatu benda secara hukum milik wakif dengan tujuan memanfaatkannya dalam kebajikan, sehingga kepemilikan harta wakaf tidak terlepas dari wakif bahkan dibenarkan untuk menarik kembali atau menjualnya. ${ }^{3}$ Sedangkan menurut Mazhab Maliki bahwa wakaf berarti tidak melepaskan harta yang diwakafkan dari kepemilikan wakif, namun wakaf mencegah wakif untuk melepaskan harta tersebut kepada yang lain, sehingga wakif membolehkan pemanfaatan untuk kebajikan dan tidak boleh menarik kembali manfaatnya. ${ }^{4}$

Menurut Mazhab Syafi'I dan Ahmad bin Hambali bahwa wakaf ialah melepaskan harta yang diwakafkan dari kepemilikan wakif dengan menyedekahkan manfaatnya sehingga status harta tersebut ialah milik Allah SWT semata. Dengan begitu dapat disimpulkan bahwa wakaf merupakan perbuatan wakif untuk memisahkan atau menyerahkan sebagian harta benda yang dimiliki dimanfaatkan guna kesejahteraan

${ }^{3}$ H.M. Athoillah, Hukum Wakaf, (Bandung: Yrama Widya, 2014), 89.

4 A. Zamakhsyari; Rifqi Qowiyul Iman (2018), “Nazir Wakaf Profesional, Standarisasi dan Problematika", Li Falah: Jurnal Studi Ekonomi dan Bisnis Islam, 3(2), 16. 
masyarakat, baik selamanya atau dalam jangka waktu tertentu. Menurut Mazhab Hambali, benda yang diwakafkan merupakan benda yang bersifat kekal dan dapat diperjualbelikan dikarenakan wakaf dilaksanakan bukan dalam jangka waktu tertentu namun selamanya. ${ }^{5}$ Landasan hukum terkait wakaf terdapat pada firman Allah Swt. dalam Surat Ali-Imran ayat 92:

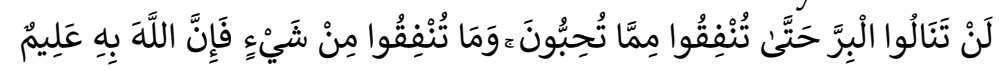
Artinya: "Kamu sekali-kali tidak sampai kepada kebajikan (yang sempurna), sebelum kamu menafkahkan sebagian harta yang kamu cintai, dan apa saja yang kamu nafkahkan. Maka sesungguhnya Allah mengetahuinya". Dengan begitu menurut jumhur ulama bahwa anjuran untuk melakukan infak secara umum tersebut dapat melalui wakaf.

Kemudian sebagaimana dalam Hadits Rasulullah Saw. Dari Ibnu Umar r.a (dilaporkan) bahwasannya Umar Ibn al-Khattab telah memperoleh sebidang tanah dari Khaibar, lalu beliau datang kepada Nabi Saw untuk meminta anjuran beliau tentang tanah tersebut, Umar berkata "Wahai Rasulullah, saya memperoleh sebidang tanah di Khaibar yang selama ini belum pernah saya peroleh harta yang lebih berharga daripadanya. Apa instruksimu mengenai harta itu? Rasulullah bersabda: Jika engkau mau, engkau dapat menahan pokoknya (melembagakan bendanya) dan menyedekahkan manfaatnya". Kemudian Umar menyedekahkan tanah itu dengan ketentuan tidak boleh dijual, dihibahkan atau diwariskan. Ibnu Umar berkata: Umar meyedekahkannya kepada orang fakir, kaum kerabat, bidak belian, sabilillah, ibn sabil dan tamu. Dan tidak dilarang bagi orang yang menguasai tanah wakaf itu (mengurus) untuk makan dari hasilnya dengan cara baik (sepantasnya) atau makan dengan tidak bermaksud menumpuk harta (HR Bukhari). ${ }^{6}$

Di Indonesia, wakaf diatur dalam Undang-Undang No. 41 Tahun 2004 tentang Perwakafan dan PP Np. 42 tentang Pelaksanaan Wakad. Lembaga yang menaungi wakaf di Indonesia ialah Badan Wakaf Indonesia (BWI) Wakaf berperan dalam mewujudkan potensi dan manfaat ekonomis harta benda wakaf untuk kepentingan ibadah dan untuk memajukan kesejahteraan masyarakat berkelanjutan. ${ }^{7}$

Wakaf memilki tujuan umum dan tujuan khusus dalam pelaksanaannya. Adapun tujuan umum wakaf ialah sebagai fungsi sosial. Dalam menjalankan fungsi sosial tersebut ditunjukkan bahwa wakaf memberikan kesempatan bagi yang kaya untuk menyantuni yang miskin, yang cerdas membimbing yang bodoh, yang kuat menolong yang lemah sehingga memberikan hikmah bahwa seorang muslim memberi manfaat

\footnotetext{
5 Taqiyuddin Abi Bakr, Kifayah al Akhyar Juz 1, (Mesir: Dar al_kitab al-Araby, tt) 319.

${ }_{6}$ Ruslan Abdul Ghofur; Isnayati Nur (2013), “Pemberdayaan Masyarakat melalui Optimalisasi Pengelolaan Wakaf Tunai (Studi Kasus pada LAZ Baitl Maal Hidayatullah dan Yatim Mandiri Cabang Lampung)", Inferensi: Jurnal Penelitian Sosial Keagamaan, 7(2), 15-19.

${ }^{7}$ Kementerian Agama Republik Indonesia, Panduan Pengelolaan Wakaf Tunai, 2013.
} 
kepada muslim yang lain. ${ }^{8}$ Dengan demikian wakaf merupakan sarana untuk melakukan kebajikan sebagai upaya untuk mendekatkan diri kepada Allah serta menjalin interaksi sesama manusia. ${ }^{9}$ Sementara tujuan khusus dari wakaf ialah mewujudkan potensi dan manfaat ekonomi dari harta benda. Wakaf dimaksudkan sebagai terciptanya sarana dan prasarana bagi kepentingan umum sehingga terwujudnya kesejahteraan dalam hal ibadah maupun muamalah. Dalam pelaksanaan wakaf terdapat 6 rukun yang harus terpenuhi, yakni orang yang berwakaf (waqif), benda yang diwaqafkan (mauquf), penerima waqaf (mauquf 'alaih), penyerahan lafaz penyerahan (sighat), pengelola wakaf (nazhir), dan jangka waktu tertentu atau tak terbatas.

Menurut Ahmad Azhar Basyir, wakaf dari segi peruntukkannya dibagi menjadi 2, yakni:

a. Wakaf ahli, yaitu wakaf yang diperuntukkan bagi orang-orang tertentu, seperti keluarga wakif atau bukan. Wakaf ini diperuntukkan bagi kepentingan dan jaminan sosial terhadap keluarga atau kerabat. Sehingga wakaf ini memberikan manfaat yang terbatas.

b. Wakaf umum (khairi), yaitu wakaf yang diperuntukkan untuk kepentingan agama dan umat secara umum. Sehingga wakaf ini dapat memberikan manfaat yang tidak terbatas karena dapat dinikmati oleh masyarakat secara luas dan merupakan sarana untuk menyelenggarakan kesejahteraan masyarakat, baik dalam bidang sosial ekonomi, pendidikan, keagamaan, dan lain sebagainya. ${ }^{10}$

Wakaf berdasarkan jenis harta dapat digolongkan menjadi 3, yakni:

a. Wakaf Benda Tidak Bergerak

Mengacu dalam Pasal 16 Ayat 2 UU No. 41 Tahun 2004, benda tidak bergerak tersebut diantaranya tanah, bangunan atau bagian dari bangunan, tanaman dan benda lain yang berkaitan dengan tanah, hak milik atas satuan rumah susun, serta benda tidak bergerak lainnya sesuai dengan ketentuan syariah dan peraturan perundang-undangan yang berlaku. Selain itu, benda tidak bergerak yang dapat diwakafkan merupakan benda yang telah berstatus hak milik dan badan-badan sosial kegamaan.

b. Wakaf Benda Bergerak Berupa Uang

Mengacu pada Pasal 28 Undang-Undang No. 41 Tahun 2004, wakif dapat mewakafkan benda bergerak yang berupa uang melalui lembaga keuangan syariah yang telah ditunjuk. Mazhab Maliki memperbolehkan untuk mewakafkan harta bergerak berupa uang dikarenakan sifatnya

\footnotetext{
${ }^{8}$ Abu Su'ud, Risalah fi Jawazi Waqf al-Nuqud, (Beirut: dar Ibn Hazm, tt), 20-21.

${ }^{9}$ Muhammad Abid Abdullah Al-Kabisi, Hukum Wakaf (Depok: IIMan Press, 2004), 83.

${ }^{10}$ Nurfaidah M (2016), “Wakaf dan Pemberdayaan Ekonomi Syariah”, Jurnal al-Adl, 9(1), 23.
} 
yang kekal tidak harus ada dalam syarat sahnya wakaf. Sedangkan mazhab Syafi'I dan Mazhab Hambali memperbolehkan wakaf benda bergerak berdasarkan status abadi dan kekalnya harta tersebut. Sesuai dengan Fatwa Majelis Ulama Indonesia (MUI) tanggal 11 Mei 2002, wakaf uang tersebut dapat berupa uang tunai atau dalam bentuk surat berharga dengan nilai pokok wakaf uang yang dijaga kelestariannya sehingga tidak boleh dijual, dihibahkan atau diwarskan. Tujuan diperbolehkannya wakaf uang ini ialah melengkapi perbankan Islam dalam produk wakaf uang, mendorong minat dalam penggalangan tabungan sosial, serta meningkatkan investasi sosial dikarenakan wakaf uang lebih fleksibel dan tidak terbatasi oleh pendistribusian. Wakaf uang ini memiliki keunggulan diantaranya jumlah yang bervariasi sehingga siapapun yang memiliki dana terbatas dapat mewakafkannya, melalui wakaf uang ini dapat disalurkan untuk memproduktifkan wakaf bergerak ataupun kegiatan-kegiatan produktif lainnya untuk kesejhteraan umat.

c. Wakaf Benda Bergerak Selain Uang

Wakaf ini dapat berupa logam mulia, kendaraan, hak katas kekayaan intelektual seperti hak cipta, hak merek dagang, hak paten, hak sewan, dan lain sebagainya. ${ }^{11}$

\section{Pemaknaan Sukuk dalam Islam}

Surat Berharga Syariah Negara (SBSN) atau yang dikenal dengan istilah Sukuk merupakan salah satu instrumen investasi yang diterbitkan oleh institusi atau emiten syariah. Sukuk berasal dari bahasa Arab yaitu sakk yang berarti dokumen atau sertifikat. ${ }^{12}$ Definisi sukuk berdasarkan fatwa No. 32/DSN-MUI/IX/2002 ialah sebagai surat berharga jangka panjang berdasarkan prinsip syariah yang dikeluarkan oleh emiten kepada pemegang obligasi syariah yang mewajibkan emiten untuk membayar pendapatan kepada pemegang obligasi syariah yang berupa bagi hasil margin atau fee, serta membayar kembali dana obligasi saat jatuh tempo. Sukuk ini mengakui kepemilikan secara proporsional dari suatu aet yang ada dan terdevirifikasi, serta adanya jaminan terhadap arus kas yang ada atau dihasilkan di masa mendatang pada periode tertentu. Berdasarkan The Accounting and Auditing Organisation for Islamic Financial Institution (AAOFI) No.17 tentang Sukuk Investasi mendefinisikan sukuk sebagai sertifikat yang memiliki nilai sama sebagai bukti kepemilikan yang tidak dibagikan

11 Dunyati Ilmiah (2019), “Optimalisasi Asset Wakaf melalui Sukuk Wakaf di Indonesia”, Jurnal Ekonomi Syariah Indonesia, IX(2), 138-146.

12 Syamsul Anwar, Studi Hukum islam Kontemporer, (Jakarta: RM Books, 2007), 88. 
atas suatu asset, hak manfaat, dan jasa-jasa atau kepemilikan atas proyek atau kegiatan investasi tertentu. ${ }^{13}$

Ada beberapa perbedaan sukuk dengan obligasi konvensional dari sisi akad dan hubungan terhadap sektor riil. Dilihat dari sisi akad, transaksi sukuk diterbitkan dengan berbagai bentuk akad yang bergantung pada transaksi yang digunakan. Akad yang dapat digunakan dalam penerbitan sukuk dalam bentuk transaksi berbasis jual beli yaitu mudharabah dan musyarakah, bentuk transaksi jual beli yaitu murabahah, salam, dan istishna', kemudian transaksi yang berbasis sewa ialah ijarah. Sedangkan pada obligasi konvensional hanya berbasis pada bunga. ${ }^{14}$ Selain itu, sukuk lebih kompetitif dibandingkan dengan obligasi konvensional dikarenakan sukuk membiayai sektor riil dengan kemungkinan peroleh dari bagi hasil pendapatan lebih tinggi. Mengutip dari kitab al-Muamalah al-Maliyah al$M u$ 'asiroh bahwa obligasi yang dilarang oleh syariah, baik dalam penerbitan, pembelian maupun perputarannya dikarenakan adanya pembayaran jumlah dengan bunga, komisi dan manfaat yang disyaratkan dikarenakan hal tersebut termasuk riba. ${ }^{15}$

Kemudian dalam penjualan obligasi juga dilarang menjual dengan harga yang lebih rendah dari nilai nominalnya dan pemilik obligasi akan mendapatkan keuntungan dari perbedaan sebagai diskon untuk obligasi yang disebut obligasi tanpa adanya kupon. Alternative yang digunakan dalam obligasi yang diperbolehkan dalam Islam ialah obligasi yang diakibatkan oleh kondisi perusahaan yang sedang deficit sehingga membutuhkan modal untuk meningkatkan dan melanjutkan proyek yang produktif sebelumnya melalui cara yang saha, seperti menawarkan untuk berlangganan saham baru atau menjadi investor baru. ${ }^{16}$

Kemudian alternative lain, apabila negara membutuhkan dana untuk menutup deficit APBN yang dibelanjakan untuk keperluan umum, melaksanakan layanan public dan menjalankan fungsi ekonomi dan sebagainya, sehingga hal ini mendorong kesadaran bagi berbagai pihak mengenai penggunaan uang dalam jangka waktu tertentu. ${ }^{17}$ Disatu sisi terdapat pendapat yang tidak memperbolehkan transaksi obligasi karena didasarkan atas pemikiran kapitaslis yang berbasis kepentingan yaitu

\footnotetext{
${ }^{13}$ Anik Iin Emy Prastiwi (2017), “Perkembangan Instrumen Sukuk dalam Mendukung Pembangunan Infrastruktur", Jurnal Ilmiah Ekonomi Islam Surakarta, 3(3), 198.

14 Maghfira Maulidia Putri; Hendri Tanjung; Hilman Hakiem (2020), “Strategi Implementasi Pengelolaan Cash Waqf Linked Sukuk dalam Mendukung Pembangunan Ekonoi Umat: Pendekaan Analytyc Network Process (ANP)", AL-INFAQ: Jurnal Ekonomi Islam, 11(2), 204-224.

15 Ascarya (2010),

${ }^{16}$ Muhammad Iqbal Fasa (2016), “Sukuk: Teori dan Implementasi”, Li Falah: Jurnal Studi Ekonomi dan Bisnis Islam, 1(1), 80-83.

${ }^{17}$ Muhammad Othoman Tsabir, al-Muamalah al-Maliyah al Mu'ashiroh (Jordania: Dar Al Nafaes, 196), 222-225.
} 
menghasilkan uang dengan uang, sedangkan dalam Islam adalah kerja yang menghasilkan uang. Disisi lain, Syekh Muhammad Abd. Dan Professor Syeikh Abd. al-Wahhab memperbolehkan bertransaksi obligasi dikarenakan terdapat ketidaksepakatan atas dasar bahwa penentuan bunga atau keuntungan dalam obligasi. ${ }^{18}$ Dalam hal ini transaksi didasarkan oleh keadilan dimana menangung keuntungan dan kerugian secara proporsional.

Istilah sukuk sebenarnya bukan hal baru dalam peradaban Islam, namun telah ada sejak abad pertama hijriyah. Umat Islam menggunakannya instrument ini dalam konteks perdagangan antar bangsa, dimana para pedagang menggunakannya sebagai dokumen yang menunjukkan kewajiban finansial yang diakibatkan dari kegiatan perdagangan dan kegiatan komersial lainnya. Di Indonesia sesuai dengan Fatwa Majma'al-Fiqh al-Islami pada 20 Maret 1990 dan Fatwa No.32/DSNMUI/IX/2002 mendorong berkembangnya sukuk sebagai kebutuhan investasi jangka panjang dan upaya untuk menghindari obligasi konvensional. Sukuk juga telah diatur dalam Fatwa No. 69/DSNMUI/VI/2008 dan Undang-Undang No. 19 Tahun 2008 tentang Surat Berharga Syariah Negara. ${ }^{19}$ Dalam kedua aturan tersebut dijelaskan bahwa sukuk yang diterbitkan harus dilandaskan pada prinsip-prinsip syariah, baik dalam mata uang rupiah.

Landasan hukum dalam Islam terhadap sukuk terdapat dalam AlQur'an, Hadits, dan Ijma' para Ulama. Sebagaimana dalam firman Allah Swt dalam Q.S. Al-Baqarah ayat 282:

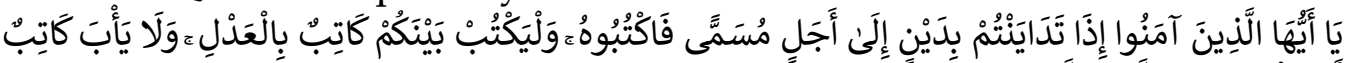

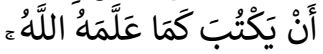

"Hai orang-orang yang beriman, apabila kamu bermu'amalah tidak secara tunai untuk waktu yang ditentukan, hendaklah kamu menuliskannya dan hendaklah seorang penulis di antara kamu menuliskannya dengan benar dan janganlah penulis enggan menuliskannya sebagaimana Allah mengajarkannya..."

Kemudian, dalam Q.S. Al-Baqarah ayat 275:

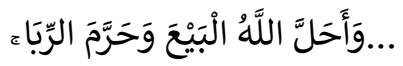
Artinya: “...Padahal Allah telah menghalalkan jual beli dan mengharamkan riba...". Maka dari itu dengan berkembangnya sukuk maka transaksi berbasis riba dapat dihindari namun berganti dengan diterapkannya transaksi bagi hasil.

\footnotetext{
${ }^{18}$ Wahab Al-Zuhaili, al-Muamalah al-Maliyah al Mu'ashiroh: Penelitian Transaksi Keuangan Kontemporer, Fatwa, dan Solusi (Damaskus: Dar Al Fikr, 2008), 488-489.

${ }^{19}$ Muhammad Ali bin Ali, Mu'jam amustholahaat al Iqtishadiyah wal Islamiah, (Riyadl: Maktabah alAbikan, 2007), 2099.
} 
Selanjutnya, sebagaimana dalam hadits Qudsi riwayat Abu Dawud, al-Daruquthi dan al-Hakim dari Abu Hurairah, Rasulullah Saw. berkata: "Allah SWT berfirman: "Aku adalah pihak ketiga dari dua orang yang berkongsi selama salah satu pihak tidak mengkhianati pihak yang lain. Jika salah satu pihak telah berkhianat. Aku keluar dari mereka".

Selain itu, Dewan Syariah Nasional (DSN) Indonesia memperbolehkan adanya kegiatan sukuk dengan berlandaskan pada kaidah fiqh berikut:

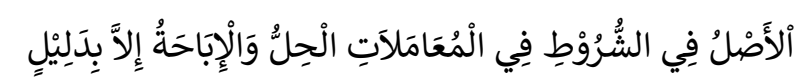

"Hukum asal muamalah itu adalah boleh kecuali ada dalil yang melarangnya"

Sukuk dapat diterbitkan oleh pemerintah maupun korporasi. Penerbitan sukuk memiliki peranan dalam penyeimbang neraca dan mendukung anggaran pemerintah, dimana sukuk dapat memperluas sumber pembiayaan selain dari obligasi dan sumber lainnya. Selain itu sukuk juga dapat mendorong pertumbuhan dan perkembangan pasar keuangan Islam di Indonesia. Adanya sukuk sebagai bentuk pendanaan sekaligus investasi yang ditawarkan sesuai dengan ketentuan dan akad yang berlaku untuk menghindari riba.

\section{Metode Penelitian}

Penelitian ini merupakan jenis penelitian studi literatur dengan pendekatan kualitatif. ${ }^{20}$ Penelitian ini menggunakan studi kepustakaan yang diperoleh dari kitab, buku, dan situs website, jurnal, dokumen penelitian terdahulu yang memiliki kaitan dengan permasalahan yang akan dikaji. Selanjutnya, data-data yang diperoleh dianalisis menggunakan metode deskriptif kualitatif, yaitu bahan-bahan dan materi akan dipelajari dan dianalisis sehingga dapat ditarik kesimpulan sehingga terbentuk kajian yang relevan dengan tema penelitian. ${ }^{21}$

\section{Hasil Dan Pembahasan}

Pertumbuhan pasar keuangan syariah di Indonesia terus meningkat, sehingga mendorong terbentuknya instrumen-instrumen investasi yang baru. Cash Waqf Linked Sukuk atau yang disingkat dengan CWLS merupakan inovasi pemerintah dalam instrumen investasi. CWLS merupakan sukuk yang berbasis wakaf uang, dimana dana wakaf yang terkumpul diinvestasikan melalui sukuk negara yang aman dan bebas risiko default. CWLS ini bertujuan untuk mensejahterakan ekonomi rakyat karena dikelola untuk membantu pembiayaan fiskal dalam bidang sosial,

\footnotetext{
${ }^{20}$ Asfi Manzilati, Metodologi Penelitian Kualitatif: Paradigma, Metode dan Aplikasi, (Malang: UB Press, 2017), 198.

${ }^{21}$ Ajat Rukajat, Pendekatan Peneltiian Kualitatif, (Yogyakarta: Deepublish, 2018), 59.
} 
seperti pendidikan dan kesehatan. ${ }^{22} \mathrm{Hal}$ ini sesuai dengan Izzuldin bin Abd As-Salam dalam kitab Qawa'id al-Ahkam fi Mushalih al-Anam bahwa seluruh syariat merupakan maslahat, baik dengan menolak mafsadat atau menerima maslahat. Lebih lanjut, sesuai dengan kaidah fikih yaitu "meraih kemaslahatan dan menolak mafsadat" dan "hukum asal dalam muamalah adalah boleh sampai ada dalil yang menunjukkan keharamannya". Sehingga dapat disimpulkan bahwa secara kaidah fikih Cash Waqf Linked Sukuk (CWLS)diperbolehkan dalam Islam.

Cash Waqf Linked Sukuk (CWLS) merupakan surat utang syariah atau sukuk yang berbasis wakaf uang, dimana dana yang terkumpul diinvestasikan pada sukuk negara. Sehingga dapat membantu pembiayaan fiskal dalam konteks sosial, seperti pada bidang edukasi, kesehatan, dan pembangunan. ${ }^{23}$ Tujuan dari pengembangan Cash Waqf Linked Sukuk (CWLS) yaitu memudahkan masyarakat untuk berwakaf uang yang aman dan produktif, mendukung pengembangan dana investasi sosial dan wakaf produktif di Indonesia, mendukung Gerakan Wakaf Nasional, penguatan ekosistem wakaf di Indonesia dan mendorong pertumbuhan ekonomi yang inklusif dan berkelanjutan.

Selanjutnya, dengan terbitnya landasan hukum Indonesia yaitu UU No. 41 Tahun 2004 tentang Wakaf dan UU No. 19 Tahun 2008 tentang Surat Berharga Syariah Negara (SBSN) turut mendukung instrumen Cash Waqf Linked Sukuk (CWLS) sehingga legalitasnya dapat dipertanggungjawabkan. Mengacu pada Fatwa DSN-MUI No. 131/DSN-MUI/X/2019 tentang Sukuk Wakaf menjadi pendorong untuk diterbitkannya CWLS yang dilandaskan pada prinsip syariah, dimana terdapat ketentuan-ketentuan yang mengatur pelaksanaan transaksi dalam wakaf yang berbasis sukuk ini. Ketentuanketentuan tersebut terdiri atas ketentuan hukum, ketentuan umum, ketentuan terkait akad, ketentuan terkait nazhir, hingga ketentuan terkait mekanisme sukuk. Hal ini sekaligus dapat mendorong pengembangan produk dalam pasar keuangan syariah yang memiliki tujuan dalam rangka optimalisasi asset wakaf dan imbal hasil sukuk bagi keperluan ibadah sekaligus kesejahteraan secara umum.

Cash Waqf Linked Sukuk memiliki beberapa keunggulan diantaranya: a) terdapat fasilitasi untuk wakif uang sehingga dapat dimanfaatkan bagi kegiatan-kegiatan yang produktif; b) wakaf uang ditempatkan dalam instrumen yang aman dan bebas dari risiko yaitu pada sukuk negara; c) seluruh atau 100\% dana akan dibayarkan kembali untuk wakif ketika jatuh

\footnotetext{
${ }^{22}$ Tahmoures (2013), “Compare and Contrast Sukuk (Islamic Bonds) with Conventional Bonds, Are They Compatible?", the Journal of Global Business Management, 9(1), 44-52.

${ }^{23}$ Nurlaili Adkhi Rizfa Faiza, "Cash Waqf Linked Sukuk sebagai Pembiayaan Pemulihan Bencana Alam di Indonesia", Tesis (Surabaya: UIN Sunan Ampel, 2019)
} 
tempo; d) hasil dari investasi sukuk wakaf akan dimanfaatkan untuk pembentukan asset wakaf baru dan pembiayaan bagi kegiatan sosial; e) calon wakif dengan jumlah wakaf uang tertentu dapat mengusulkan proyek atau kegiatan sosial yang akan dilakukan dan dibiayai; f) Badan Wakaf Indonesia dikecualikan dari perpajakan sehingga hasil investasi didapatkan secara kompetitif. ${ }^{24}$

Dilihat dari sisi kemaslahatannya, Cash Waqf Linked Sukuk (CWLS) dapat memberikan keberlanjutan perekonomian. Hal ini ditunjukkan bahwa dalam keuangan Islam terdapat sektor sosial yang berpotensi untuk mendorong sektor komersial dan memberikan hubungan imbal balik yang memberikan manfaat besar dalam menyejahterakan masayarakat dan pembangunan ekonomi berkelanjutan. ${ }^{25}$ Dengan begitu, CWLS dapat memberikan pembiayaan bagi sektor komersial sekaligus sektor sosial. Pembiayaan tersebut disalurkan kepada sektor produktif untuk menggerakkan ekonomi riil kemudian hasil dari kegiatan produktif tersebut disalurkan pada sektor sosial yang membutuhkan, seperti institusi pendidikan tinggi, penanganan pembiayaan daerah pasca bencana, dan sektor sosial lainnya.

\section{Skema 1. Mekanisme Pelaksanaan Cash Waqf Linked Sukuk}

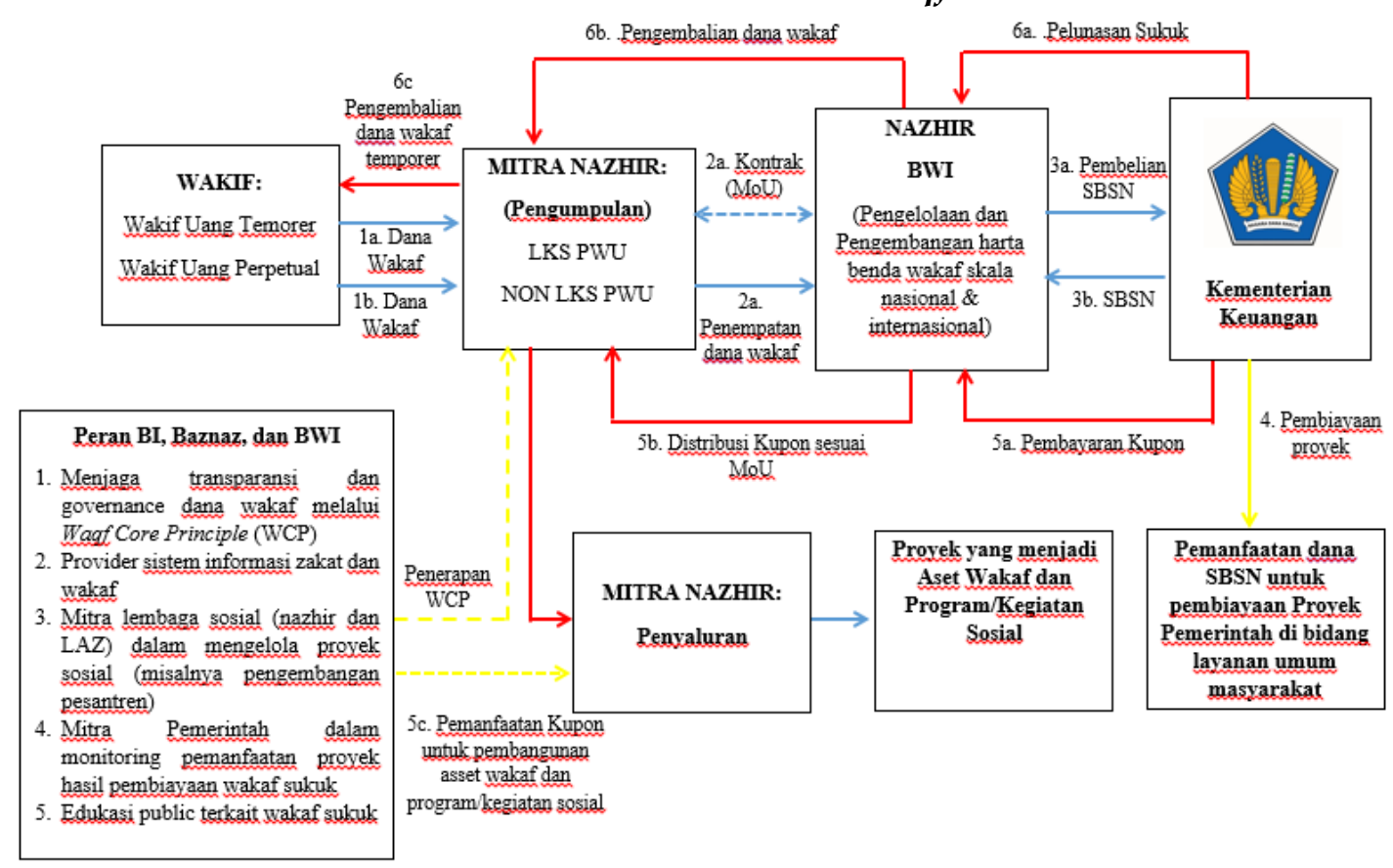

24 Umu Karomah Yaumuddin, Sukuk: Sebuah Alternatif Instrument Investasi, Investasi Syariah, (Yogyakarta: Kreasi Wacana, 2008), 9-10.

${ }^{25}$ Muhammad Kamal Zubair (2012), “Obligasi dan Sukuk dalam Perspektif Kuangan Islam: Suatu Kajian Perbandingan", Jurnal Ilmu Syariah dan Hukum, 46(1), 271-296. 
Berikut penjelasan dari skema mekanisme pelaksanaan Cash Waqf Linked Sukuk diatas:

1. Wakif mewakafkan uang yang dimiliki dan ingin diwakafkan melalui mitra nazhir atau LKS-PWU kepada nazir dengan periode waktu tertentu (minimal 5 tahun) atau selamanya.

2. Wakif menyetorkan dana wakaf uang tersebut ke rekening mitra nazhir di LKS-PWU

3. Setelah itu, wakif melakukan Ikrar Wakaf dihadapan pejabat bank yang ditunjuk sebagai Pembuat Akta Ikrar Wakaf (PPAIW).

4. Setoran dana wakaf uang dari wakif akan ditempatkan pada rekening wadiah atas nama mitra nazhir sebelum ditempatkan ke rekening nazhir BWI.

5. Apabila telah terkumpul dana sebesar jumlah kumulatif dari seluruh mitra nazhir yaitu mencapai 50 miliar maka BWI dapat memindahkan ke rekening BWI di LKS PWU sebagai wadiah.

6. Kemudian dana yang telah dihimpun digunakan untuk membeli SBSN yang telah diterbitkan oleh Kementerian Keuangan dalam jangka waktu tertentu.

7. Kementerian Keuangan melakukan pembayaran kupon SBSN kepada Nazhir BWI sesuai dengan kontrak yang telah disepakati di awal perjanjian.

8. Kupon yang telah dibayarkan dikurangi sebanyak $10 \%$ oleh nazhir sebagai biayan pengelolaannya kemudain disalurkan melalui mitra nazhir untuk membiayai pembangunan asset wakaf atau dasilitas umum.

9. Kementerian Keuangan mengembalikan dana wakaf uang kepada BWI setelah SBSN atau Sukuk Negara saat jatuh tempo.

10. BWI memberikan perintah kepada mitra nazhir dan LKS-PWU untuk melakukan pengembalian dana wakaf uang untuk jangka waktu tertentu kepada wakif.

11. Pengembalian dana wakaf uang kepada wakif melalui bank operasional yang telah ditunjuk BWI.

12. Kementerian Agama dan Badan Wakaf Indonesia bertindak sebagai pengawas dalam melakukan program wakaf uang link sukuk atau Cash Waqf Linked Sukuk. ${ }^{26}$

Berdasarkan skema mekanisme pelaksanaan Cash Waqf Linked Sukuk (CWLS) tersebut menunjukkan bahwa terpenuhinya rukun-rukun wakaf, yaitu adanya orang yang berwakaf (waqif), benda yang diwaqafkan (mauquf), penerima waqaf (mauquf 'alaih), penyerahan lafaz penyerahan

${ }^{26}$ Hamli Syaifullah; Ali Idrus (2019), “Inovasi Pelayanan Wakaf Produktif Era Digital: Studi kasus di Yayasan Wakaf Bani Umar", ZIZWAF: Jurnal Zakat an Wakaf, 6(2), 114-128. 
(sighat), pengelola wakaf (nazhir), dan jangka waktu tertentu atau tak terbatas. Pelaksanaan CWLS melibatkan 5 stakeholder yaitu: Bank Indonesia sebagai akselator pelaksaananya dan Bank Kustodian; Badan Wakaf Indonesia (BWI) sebagai regulator, leader, dan nazhir yang mengelola wakaf; Kementerian Keuangan sebagai issuer SBSN dan pengelola dana di sektor riil; Nazhir Wakaf Produktif sebagai mitra BWI yang melakukan penghimpunan dana wakaf, Bank Syariah sebagai Lembaga Keuangan Syariah Penerima Wakaf Uang (LKS-PWU) dan Bank Operasional BWI. Selanjutnya, dalam penerbitan Cash Waqf Linked Sukuk digunakan beberapa akad, diantaranya mudharabah, ijarah, wakalah bi alIstishmar, musyarakah atau akad lainnya yang sesuai dengan prinsip syariah. ${ }^{27}$

Pertama, Sukuk yang diterbitkan menggunakan akad mudharabah didasarkan pada perjanjian dimana satu pihak menyediakan modal (investor sebagai shabibul mal) dan pihak lain yang mengelola dana (mudharib) yang merupakan nazhir, kemudian keuntungan dari kerjasama tersebut dibagi berdasarkan prosentase bagi hasil dan diberikan padasaat jatuh tempo sesuai kesepakatan dan kerugian ditanggung oleh pemilik dana. Namun apabila terjadi kerugian akibat kesalahan nazhir, maka nazhir bertanggung jawab sebatas dana hasil pengembangan asset wakaf dan tidak boleh mengurangi asset.

Kedua, sukuk yang diterbitkan dengan skema akad ijarah, apabila diterbitkan oleh nazhir maka nazhir bertindak sebagai emiten yang melakukan akad sukuk atas manfaat asset wakaf dengan investor dan ujrah disepakati nilainya pada saat akad, baik itu berupa uang, barang, maupun bangunan. Namun apabila diterbitkan oleh pihak ketiga (bukan nazhir) maka nazhir akan melakukan akad dengan pihak ketiga tersebut sesuai dengan prinsip syariah seperti akah Hikr atau akad Ijarah.

Ketiga, Sukuk yang diterbitkan dengan skema akad Wakalah bi alIstitsmar, dimana investor (muwakkil) melakukan akad tersebut dengan wakil yaitu nazhir atau pihak ketiga yang menerbitkan sukuk. Dalam hal ini seluruh hasil dari dana sukuk yang telah dikelola menjadi hak muwakkil pada saat jatuh tempo atau sesuai kesepakatan.

Keempat, Sukuk yang diterbitkan dengan skema akad musyarakah dilakukan anatar investor dengan penerbit sukuk (nazhir). Nazhir juga dapat bertindak sebagai syarik aktif atau pihak ketiga yang menerbitkan sukuk. Masing-masing syarik berhak atas bagi hasil yang menjadi

\footnotetext{
${ }^{27}$ Hamli Syaifullah; Ali Idrus (2019), “Manajemen Pengembangan Wakaf Produktif Era Digital di Lembaga Wakaf Bani Umar", al-Khidmat: Jurnal Ilmiah Pengebdian Kepada Masyarakat, 2(2), 5-14.
} 
bagiannya dan penerbit sukuk wajib mengembalikan modal musyarakah kepada syarik. ${ }^{28}$

Dalam pengelolaan dana wakaf tersebut dikelola pada kegiatan usaha yang halal dan sesuai dengan prinsip syariah. Dana wakaf tersebut digunakan untuk pembiayaan proyek ekonomi sekaligus soial guna mendorong perekonomian nasional diantaranya sebagai berikut:

1. Mendorong pertumbuhan perbankan syariah yang sekaligus mendorong perbankan syariah untuk menyalurkan pembiayaan bagi pelaku usaha karena penerima manfaat dari CWLS disalurkan melalui beberapa program sosial, salah satunya pemberdayaan ekonomi bagi UMKM di Rumah Wakaf.

2. Membiayai aset produktif, seperti penggunaan bagi membangun inkubator bagi pengembangan usaha serta membuka lapangan pekerjaan melalui usaha di sektor riil. Dengan adanya inkubator yang difungsikan sebagai pemberdayaan ekonomi tersebut dapat mendorong pelaku usaha memaksimalkan potensi yang ada, baik sumber daya alam maupun sumber daya manusia.

3. Mendukung pelaksanaan program sosial, melalui pembiayaan pembangunan infarstuktur sosial yang dibutuhkan di daerah seperti rumah sakit gratis bagi dhuafa (Rumah Sakit Mata Ahmad Wardi).

4. Pengembangan Endowment Fund untuk lembaga sosial yang disalurkan pada Dana Kemaslahatan BPKH.

5. Pengembangan dana CSR untuk kegiatan sosial dalam Dana CSR Korporasi dan BUMN.

6. Pemanfaatan lahan non produktif yang digunakan dimanfaatkan untuk lahan peternakan atau perkebunan yang dilaksanakan pada Wakaf Kebun Dhompet Dhuafa.

7. Memberikan fasilitas layanan kesehatan gratis bagi dhuafa yang disalurkan pada pembiayaan operasi katarak gratis. ${ }^{29}$

8. Memberikan program umrah gratis bagi guru-guru ngaji di daerah. Cash Waqf Linked Sukuk (CWLS) memberikan dampak positif yang begitu besar bagi pengembangan ekonomi berkelanjutan. Oleh karena itu, keberadaan instrumen investasi dunia dan akhirat ini cocok untuk diterapkan di Indonesia mengingat potensi aset wakaf yang begitu besar untuk dapat dijadikan produktif sejalan dengan sistem ekonomi Islam yang dilandasakan pada prinsip-prinsip syariah.

28 Nasrul Fahmi Zaki Fuadi (2018), "Wakaf sebagai Instrumen Ekonomi Pembangunan Islam”, Economica: Jurnal Ekonomi Islam, 9(1), 151-177.

${ }_{29}$ Gustani; Dwi Aditya Ernawan (2016), “Wakaf Tunai sebagai Sumber Alternatif Permodalan Lembaga Keuangan Mikro Syariah di Indonesia", Journal of Islamic Economis: Lariba, 2(2), 39-48. 


\section{Kesimpulan}

Cash Waqf Linked Sukuk merupakan inovasi dalam mengembangkan wakaf, dimana mengintegrasikan antara wakaf dengan sukuk. Cash Waqf Linked Sukuk (CWLS) merupakan surat utang syariah atau sukuk yang berbasis wakaf uang dimana dana yang terkumpul diinvestasikan pada sukuk negara. Instrumen tersebut didasarkan pada Al-Qur'an, Hadits, dan Ijma' para ulama. Pelaskanaan Cash Waqf Linked Sukuk pun telah diatur dalam Fatwa DSN-MUI No. 131/DSN-MUI/X/2019 tentang Sukuk Wakaf. Dalam prespektif ekonomi Islam, implementasi pengelolaan Cash Waqf Linked Sukuk telah dilakukan sesuai dengan prinsip-prinsip syariah yang telah ditentukan.

Pelaksanaan CWLS telah memenuhi rukun-rukun yang disyaratkan yaitu dengan adanya orang yang berwakaf (waqif), benda yang diwaqafkan (mauquf), penerima waqaf (mauquf 'alaih), penyerahan lafaz penyerahan (sighat), pengelola wakaf (nazhir), dan jangka waktu tertentu atau tak terbatas. Kemudian dalam penerbitan sukuk diapat dilakukan oleh nazhir maupun pihak ketiga yang pelaksanaanya di dasarkan pada akad yang seusuai syariah diantaranya mudharabah, ijarah, wakalah bi al-Istishmar, musyarakah atau akad lainnya yang sesuai dengan prinsip syariah. Selain itu, dalam pengelolaan dana wakaf tersebut diperuntukkan pada kegiatankegiatan halal dan sesuai prinsip syariah dalam rangka mencapai kemaslahatan dan kesejahteraan masyarakat. Adapun penyaluran dana dilakukan untuk pembiayaan asset produktif, pengembangan kegiatan sosial, pembiayaan pembangunan sarana dan prasarana kesehatan dan pendidikan, dan pembiayaan lainnya. Cash Waqf Linked Sukuk ini berpotensi dalam mendorong pembangunan berkelanjutan dalam ekonomi sekaligus kegiatan sosial yang tidak hanya untuk investasi dunia namun juga investasi akhirat.

\section{Daftar Pustaka}

Ali, Muhammad Ali bin. Mu'jam amustholahaat al Iqtishadiyah wal Islamiah, (Riyadl: Maktabah al-Abikan, 2007).

Anwar, Syamsul. Studi Hukum islam Kontemporer, (Jakarta: RM Books, 2007).

Athoillah, H.M. Hukum Wakaf, (Bandung: Yrama Widya, 2014).

Bakr, Taqiyuddin Abi, Kifayah al Akhyar Juz 1, (Mesir: Dar al_kitab alAraby).

Faiza, Nurlaili Adkhi Rizfa. “Cash Waqf Linked Sukuk sebagai Pembiayaan Pemulihan Bencana Alam di Indonesia", Tesis (Surabaya: UIN Sunan Ampel, 2019). 
Fasa, Muhammad Iqbal (2016), "Sukuk: Teori dan Implementasi”, Li Falah: Jurnal Studi Ekonomi dan Bisnis Islam, 1(1).

Fuadi, Nasrul Fahmi Zaki (2018), “Wakaf sebagai Instrumen Ekonomi Pembangunan Islam", Economica: Jurnal Ekonomi Islam, 9(1).

Ghofur, Ruslan Abdul; Isnayati Nur (2013), "Pemberdayaan Masyarakat melalui Optimalisasi Pengelolaan Wakaf Tunai (Studi Kasus pada LAZ Baitl Maal Hidayatullah dan Yatim Mandiri Cabang Lampung)", Inferensi: Jurnal Penelitian Sosial Keagamaan, 7(2).

Gustani; Dwi Aditya Ernawan (2016), “Wakaf Tunai sebagai Sumber Alternatif Permodalan Lembaga Keuangan Mikro Syariah di Indonesia", Journal of Islamic Economis: Lariba, 2(2).

Ilmiah, Dunyati (2019), “Optimalisasi Asset Wakaf melalui Sukuk Wakaf di Indonesia", Jurnal Ekonomi Syariah Indonesia, IX(2).

Kabisi, Muhammad Abid Abdullah. Hukum Wakaf (Depok: IIMan Press, 2004).

Kementerian Agama Republik Indonesia, Panduan Pengelolaan Wakaf Tunai, 2013.

Manzilati, Asfi. Metodologi Penelitian Kualitatif: Paradigma, Metode dan Aplikasi, (Malang: UB Press, 2017).

Nurfaidah, M. (2016), “Wakaf dan Pemberdayaan Ekonomi Syariah”, Jurnal al-Adl, 9(1).

Prastiwi, Anik Iin Emy (2017), “Perkembangan Instrumen Sukuk dalam Mendukung Pembangunan Infrastruktur", Jurnal Ilmiah Ekonomi Islam Surakarta, 3(3).

Putri, Maghfira Maulidia; Hendri Tanjung; Hilman Hakiem (2020), "Strategi Implementasi Pengelolaan Cash Waqf Linked Sukuk dalam Mendukung Pembangunan Ekonoi Umat: Pendekaan Analytyc Network Process (ANP)", AL-INFAQ: Jurnal Ekonomi Islam, 11(2).

Rukajat, Ajat. Pendekatan Peneltiian Kualitatif, (Yogyakarta: Deepublish, 2018).

Setyahadi, H. (2017), "Pengelolaan Pengembangan Wakaf Uang Berdasarkan Peraturan PemerintahNo. 42 Tahun 2006 Pasal 48 pada Bank BPD DIY Syariah", IQTISHADUNA: Jurnal Ekonomi Syariah, 2 (1).

Su'ud, Abu. Risalah fi Jawazi Waqf al-Nuqud, (Beirut: dar Ibn Hazm, tt). 
Syaifullah, Hamli; Ali Idrus (2019), "Inovasi Pelayanan Wakaf Produktif Era Digital: Studi kasus di Yayasan Wakaf Bani Umar", ZIZWAF: Jurnal Zakat an Wakaf, 6(2).

Syaifullah, Hamli; Ali Idrus (2019), "Manajemen Pengembangan Wakaf Produktif Era Digital di Lembaga Wakaf Bani Umar", al-Khidmat: Jurnal Ilmiah Pengebdian Kepada Masyarakat, 2(2).

Tahmoures (2013), "Compare and Contrast Sukuk (Islamic Bonds) with Conventional Bonds, Are They Compatible?", the Journal of Global Business Management, 9(1).

Tsabir, Muhammad Othoman. al-Muamalah al-Maliyah al Mu'ashiroh (Jordania: Dar Al Nafaes, 196).

Yaumuddin, Umu Karomah. Sukuk: Sebuah Alternatif Instrument Investasi, Investasi Syariah, (Yogyakarta: Kreasi Wacana, 2008).

Zamakhsyari, A.; Rifqi Qowiyul Iman (2018), "Nazir Wakaf Profesional, Standarisasi dan Problematika", Li Falah: Jurnal Studi Ekonomi dan Bisnis Islam, 3(2).

Zubair, Muhammad Kamal (2012), “Obligasi dan Sukuk dalam Perspektif Kuangan Islam: Suatu Kajian Perbandingan", Jurnal Ilmu Syariah dan Hukum, 46(1).

Zuhaili, Wahab. al-Muamalah al-Maliyah al Mu'ashiroh: Penelitian Transaksi Keuangan Kontemporer, Fatwa, dan Solusi (Damaskus: Dar Al Fikr, 2008). 